\title{
Understanding the Social Care Crisis in England Through Older People's Lived Experiences
}

\author{
Lizzie Ward, Mo Ray, and Denise Tanner
}

\section{INTRODUCTION}

In the final chapter of Caring Democracy, Joan Tronto poses the question "how do we go from a society that is primarily concerned with economic production to one that also emphasises care?" $(2013,169)$. As illustrated in the contributions to this collection, participation in political processes and in decision-making about responsibilities for care are understood as

L. Ward $(\bowtie)$

School of Applied Social Science, University of Brighton, Brighton, UK e-mail: E.Ward@brighton.ac.uk

M. Ray

School of Health and Social Care, University of Lincoln, Lincoln, UK e-mail: Mray@lincoln.ac.uk

D. Tanner

Department of Social Work and Social Care, University of Birmingham, Birmingham, UK

e-mail: D.L.Tanner@bham.ac.uk

(C) The Author(s) 2020

P. Urban, L. Ward (eds.), Care Ethics, Democratic Citizenship

and the State, International Political Theory,

https://doi.org/10.1007/978-3-030-41437-5_11 
crucial in answering this question (see chapters by Heier, Bourgaut and White, this volume). Who is excluded from political participation, and how to challenge the power of those who operate from a position of 'privileged irresponsibility' in the allocation of care, are key areas of concern for making democracy more caring and caring more democratic. However, there is a further question concerning participation in how knowledge about care is produced? The 'epistemological dimension' of care is recognised in care ethics through the concept of 'responsiveness' in which attention to the care-receiver's experience informs the care process at the micro level. But what counts as 'knowledge' about care in political processes and policy decisions at the macro level is also highly significant. Yet, the inclusion of care-receivers at the level of 'knowledge production' is less developed in care scholarship. Within the academic and practice worlds another dimension of participation operates, whereby most knowledge about care is produced without the inclusion of care-receivers and with little regard to their lived experiences of care. This chapter draws on empirical research that was co-produced with older people about lived experiences of care within the English social care system. We argue that building knowledge care with those who have lived experience is necessary for the democratisation of care. Knowledge produced from lived experience can make sense of theoretical concepts and consider their relevance to 'everyday life'. But crucially, within the current neoliberal context where only certain types of knowledge are admissible, the actual experiences of care under neoliberalism directly challenge the assumptions that underpin the consumer choice rationale that supports the marketisation of care.

If we are to shift the dominant focus away from the economic domain, Tronto suggests that we need to rethink the relationship between the state and the market $(2013,170)$. The ascendency and dominance of neoliberalism, as the economic-political system of organising contemporary societies, has resulted in the prioritisation of markets above all human life. This is one of the biggest roadblocks to actualising the 'caring democracy' that Tronto envisages. One starting point for the work that needs to be done to break the neoliberal hold over our thinking is to recognise that neoliberalism began as a man-made (literally) set of ideas which originated in the works of economists, such as Hayek and others, in their mid-twentieth-century fears of centralised state control of the economy (Metcalf 2017). Early neoliberal thought considered the only 'scientific' means of assessing and evaluating all aspects of life is through the market and the price mechanism. Its enduring legacy, and indeed legitimacy, as the underpinning framework of the audit and assessment culture which now dominates many developed 
welfare societies and public services, merits serious scrutiny. What constitutes knowledge within neoliberal thought is problematic, particularly in relation to care, as the orientation to 'objective' frames of reference relegates lived experiences of care to the realm of opinion or anecdote.

Many have offered critiques on the incompatibility of market mechanisms and equitable health and care provision (Clarke et al. 2007; Fotaki 2009; Mol 2008; Williams and Brennan 2012). But looking at experiences of care can help us understand why these are so incompatible. As we aim to show in this chapter, it is precisely knowledge based on lived experiences - the epistemological dimension of care-that exposes the failures of neoliberalism in meeting care needs. This adds weights to the argument that the current economic domination in human life stands in the way of 'caring democracy'.

The chapter's focus is social care ${ }^{1}$ in England where responsibility for the organisation and funding of care has shifted from the state to the individual. It draws on a qualitative research project about the experiences of older people who are paying for their social care. ${ }^{2} \mathrm{We}$, as academic researchers, set out to place older people's experiences at the centre of the project, within the research process as well in the empirical data we gathered. We describe this approach as the co-production of knowledge to convey our commitment to prioritising lived experiences and challenging traditional academic knowledge hierarchies. ${ }^{3}$ It involves working alongside older people as 'lay' co-researchers and taking the ethical dimensions of participatory research seriously in every aspect of the work. We describe this as 'relational research practice' in which we apply care ethics

\footnotetext{
${ }^{1}$ Care needs related to the activities of daily living, for example, dressing, washing, going to the toilet and eating.

${ }^{2}$ Ethical issues in self-funded social care: co-producing knowledge with older people funded by the Wellcome Trust 2017-2020. The research aimed to understand the ethical dimensions related to risk and responsibility in self-funded care by using a 'co-production' approach which centralises older people's lived experiences. See http://www.olderpeopleselffundingcare.com/.

${ }^{3}$ It should be acknowledged that the term 'co-production' in in the UK has become a widely used concept. Arguably its adoption into the mainstream, for example in UK Higher Education Institutes, research funding bodies and so on as part of the 'Impact' agenda, could be understood as the co-option of a more radical understanding of the concept into a neoliberal agenda. A similar move in relation to the involvement of patients and service users in health and care services and in research can also be seen as part of a de-politicisation process linked to forcing individual choice, responsibility and self-care.
} 
to the ways we conduct research as well as conceptually in the analysis (see Ward and Gahagan 2010 for details).

It is important to say at the outset that the research and analysis we offer to illustrate our argument is bounded by the 'local' context and the particular time and place in which it was produced. It comes from a privileged part of the world, where matters concerning social rights and collective responsibilities for care are, largely assumed to be guaranteed by the post-war welfare settlement. Nevertheless, we argue that it offers a case study which illustrates the failures of the neoliberal economic framing in meeting social care needs through a system of marketised care, and this has a wider applicability to different contexts beyond the social care system in England.

Firstly, this chapter offers an overview of the transformations in social care in England. It discusses the implications of neoliberal policy objectives that have driven the changes, primarily individual responsibility and consumer choice, for older people who need care. It then turns to focus on the research we conducted with older people who are paying for their own care and draws on examples from interview data to explore in more depth the disparity between the neoliberal assumptions and actual lived experiences. Finally, we consider what these lived experiences can contribute to understanding the inadequacy of neoliberal thinking in addressing care needs and in democratising care.

\section{Austerity, Welfare and Social Care in England}

In November 2018, the UN rapporteur on extreme poverty and human rights, Philip Alston, concluded from his two-week mission to the UK that the government's austerity programme had inflicted 'great misery' on its people. The extent of poverty in the world's fifth largest economy with around 14 million people ( $20 \%$ of the UK population) living in poverty and 1.5 million so destitute that they cannot afford basic essentials was, he argued, the result of "punitive, mean-spirited and often callous" austerity policies driven by a political desire to undertake social re-engineering rather than economic necessity (United Nations 2019, 5).

In gathering his evidence Alston had spent time talking to people who were experiencing the impact of austerity policies: those who use foodbanks for daily needs; those who have lost their homes and have nowhere safe for themselves and their children to sleep; people who sell sex for money or shelter; young people who have joined gangs to survive; and 
disabled people who have lost the support packages they relied on. He concluded that the scale of austerity measures is so extreme that it represents an abandonment of the values that underpinned the Beveridge postwar social contract and informed the British welfare state:

The bottom line is that much of the glue that has held British society together since the Second World War has been deliberately removed and replaced with a harsh and uncaring ethos. A booming economy, high employment and a budget surplus have not reversed austerity, a policy pursued more as an ideological than an economic agenda. (United Nations 2019,4)

Just as shocking as the report was the government response and their "determined state of denial" (ibid., 4), which challenged the report's validity by citing statistics showing increases in the numbers of people in paid work and household income at a record high. The steadfast refusal of the government to encounter the lived experiences of people impacted by its own policies is more than the current trend of 'post-truth' politics. It reflects policymakers and politicians' reliance on 'evidence' framed by narrow outcome measures and quantifiable performance indicators to justify their claims.

The transformation of the welfare state that Alston's report highlighted does, in fact, have a longer history than the financial crises of 2008 and the introduction of the austerity measures that followed. It is part of the longer trajectory of the marketisation, privatisation and outsourcing of health and social care in the UK begun by the Thatcher government at the end of the $1970 \mathrm{~s}^{4}$ and reflected in global shifts of the privatisation of the public realm (Clarke et al. 2007). In the UK, as in many developed welfare societies, this has eroded public funding and provision of health and care which has been replaced by the rhetoric of 'choice' and the belief in the market as the most efficient means to deliver welfare services. For example, within Europe, England has been at the forefront of marketising the social care sector (Ismail et al. 2017), predominantly through the 'personalisation' policy agenda. This introduced a 'cash-for-care' approach whereby those who receive publicly funded care are given a personal

${ }^{4}$ Margaret Thatcher led the UK government between 1979 and 1990. Thatcherism, which extended beyond this period and beyond the UK, was a total rejection of the post-war welfare consensus. Thatcher was inspired by the ideas of Hayek and other neoliberals and was committed to the privatisation of public services and free market principles. 
budget to purchase their own care through a growing social care market. But since 2010 in the UK, the withdrawal of state responsibility for welfare and care has intensified through austerity politics as a response to the banking crisis and financial meltdown of 2007-2008.

What was essentially a crisis in the financial sector was ideologically reframed by the UK government ${ }^{5}$ into one of government debt and public expenditure to justify austerity measures (Clarke and Newman 2012). This was accompanied by a neo-communitarian discourse (Davies 2012) in which 'communities' and 'self-help' were the preferred solutions to the crisis whilst the 'state' was constructed as part of the problem. ${ }^{6}$ The combination of the apparent economic necessity of public spending cuts and the elevation of the role of communities has worked to further "deflect and decentralize responsibility for care and welfare" (Clarke and Newman $2012,303)$. In spending terms this has resulted in local authorities losing $49.1 \%$ of central government funding between 2010 and 2018 (National Audit Office 2018). ${ }^{7}$ It is local authorities which provide much of the infrastructure for welfare services, such as schools, libraries, parks, leisure facilities and so on which contribute to civic life as well as social care services.

There are many ways in which these spending cuts have been felt across different groups of people who need care and welfare services, for example, the closure of community transport and meals services, day centres, libraries, which have affected people with needs of all ages. Indeed, the

\footnotetext{
${ }^{5}$ This reformulation of 'the problem' was promoted by Conservative-led coalition government from 2010 to 2015 and more forcefully from 2015 onwards by the Conservative government.

${ }^{6}$ See Prime Minister Cameron's defining speech on the Big Society: "the size, scope and role of government in Britain has reached a point where it is now inhibiting, not advancing the progressive aims of reducing poverty, fighting inequality, and increasing general wellbeing. Indeed, there is a worrying paradox that because of its effect on personal and social responsibility, the recent growth of the state has promoted not social solidarity, but selfishness and individualism" (David Cameron, Hugo Young Lecture 10 November 2009. https://conservative-speeches.sayit.mysociety.org/speech/601246 accessed 21/11/18).

${ }^{7}$ Reductions in Local authority funding became a key target for Prime Minister Cameron under the austerity measures, justified as the mechanism to release 'the potential within communities' (DH 2010,9): “Resource pressures make it even more important to take an approach that changes the relationship between citizen and state. This does mean people and communities playing more of a role in supporting themselves and others. In exchange, they need more freedom to shape their support and public services must remove barriers to this freedom" (DH 2010, 9).
} 
real impact of these public funding cuts was clearly evident to Alston during his UN mission. But it is the provision of social care for older people who have complex needs, where the impacts have been particularly acute. As early as 2014 the National Audit Office (the official body which scrutinises public spending) were warning that the social care system was unsustainable:

Pressures on the care system are increasing. Providing adequate social care poses a significant public service challenge and there are no easy answers. People are living longer and some have long-term and complex health conditions that require managing through care. Need for care is rising while public spending is falling and there is unmet need. Departments do not know if we are approaching the limits of the capacity of the system to continue to absorb these pressures. (National Audit Office 2014, 11)

The way in which state-supported care is organised in the UK is complex. Healthcare provided universally via the National Health Service (NHS) was from its inception, and still remains, largely free at the point of use ${ }^{8}$ financed and accountable through central government. In contrast, statutory social care is means-tested and administered at a local level, with regional variations in England, Northern Ireland, Scotland and Wales. Local authorities typically only fund the care of those with high needs and limited finances. How 'high needs' and 'limited finances' are defined depends largely on political decisions in the allocation of spending across local authority services, although there are national financial thresholds and eligibility criteria. In England, where the research we draw on was carried out, overall spending on statutory adult social care has fallen substantially as local authorities have made 'budget savings' of over $£ 6$ billion since 2010 (ADASS 2017, 4). Unsurprisingly this has resulted in fewer people receiving state-funded care. The Care Quality Commission (CQC), which regulates social care in England, estimated that by 2018, 1.4 million older people did not have access to the care and support they needed (CQC 2018).

\footnotetext{
${ }^{8}$ From April 2017 NHS staff are expected to check a patient's citizenship before healthcare is given. This move has received criticism, (including from the medical profession) and claims that 'health tourists' are to blame for the funding crisis in the NHS have been viewed as a distraction from the deliberate underfunding from government, linked to the increasing privatisation of the health service and part of the wider policy of creating a 'hostile environment' towards immigration-see Stewart 2017.
} 
We can begin to see here the wide-reaching transformations within the social care system through the longer-term neoliberal restructuring and the more recent, and unprecedented, reductions in government spending for publicly funded social care. Both have led to the further commodification of care framed ideologically by consumer choice and individual responsibility. For older people, who are the focus of the research that this chapter draws on, this has particular impacts. Increasing numbers of older people now need to purchase their own care, rely on family members or simply go without it (Glendinning 2017). But what can the experiences of older people who need care and support services tell us about these fundamental changes to the welfare state? The next section turns to the research we conducted that addressed these questions.

\section{Researching Social Care with Older People}

After six years of sustained cuts in local authority budgets for social care the Kings Fund reported that "No one has a full picture of what has happened to older people who are no longer entitled to publicly funded care: the human and financial costs to them and those who care for them are mounting" (Humphries et al. 2016, 3). Partly, this is because social care research has focused mainly on publicly funded care; so although the numbers of older people who fall outside of this has increased very little attention is given to their experiences (Tanner et al. 2018). But this lack of attention to lived experiences also reflects the dominance of 'the economics' of social care policy and practice in much social care research despite the drive towards including service-user knowledge through the mainstreaming of 'service-user involvement'.

We had worked previously with older people as co-researchers on projects in designing and conducting research that enables older people to share their lived experiences on their own terms. Our decision to focus on lived experiences of self-funded care in this project was based on the realisation that older people in this situation were completely under the radar in relation to policy and social care practice. Our intention was to get under the political rhetoric that has accompanied the restructuring of welfare services and produce knowledge based in the lived experiences of older people facing the situation of purchasing their own care. Our first

\footnotetext{
${ }^{9}$ Demonstrating the involvement of patients and service users in research design and development is a requirement of NHS and government research council funding in the UK.
} 
challenge as researchers who want to democratise knowledge production, (and one which is true in relation to 'participation' more generally), is to recognise power differentials that are intrinsic to the research process and find ways to not only acknowledge but actively address these. In working through this challenge, we have developed relational research practice which explicitly recognises the value of knowledge from lived experiences of ageing and the issues that older people face. It also means being attentive to the different needs and circumstances of everyone we involve in our work as research participants and co-researchers and building supportive and trusting relationships in our research practice.

We started to explore the issues in a small pilot study where we interviewed older people who were self-funding their care. Having to pay for care can come as something of a shock for the generation of people who have contributed to national social insurance throughout their working lives and who find their contributions do not cover their care needs as they reach a point when social care becomes a necessity in their own lives. But the difficulties are not just a matter of paying and financing care; there is a wider lack of understanding about how to actually go about organising care, assessing what care services are needed, where to find these, who to trust and how much it will cost. In effect people are unprepared for becoming a 'consumer' of care within a market system, and very often this happens at a time of crisis through ill health or following a stay in hospital.

The themes that emerged from the pilot interviews focused around three areas: difficulties in accessing care; finding the right help; and managing the care. We could see that our participants were faced with making complex and possibly far-reaching decisions at a point of vulnerability, such as ill health or following discharge from hospital. Their narratives highlighted the difficulty of absorbing information at a time of crisis. There was uncertainty about knowing the right level of services they required, as their care needs were dynamic and changing, and in the absence of any statutory support to help them, they were left trying to work this out on their own.

From this initial work we developed a larger study focused on ethical challenges arising in the transformed care landscape, specifically in relation to risks and responsibilities within care relationships. We expanded the scope of the project to help us understand the relational aspects of older people's experiences by also looking at the perspectives of care providers, practitioners and local authority officials as well as the family and friends supporting older people who are self-funding. The larger study used longitudinal qualitative interviews with older people over a period of eighteen 
months to explore their care journeys and changes that happened during this time. The study was carried out in three different areas of England and in each research site academic researchers worked with older citizens as co-researchers. The co-researchers were trained in all aspects of research and worked with us on the research design, data collection, analysis and interpretation and dissemination. The research teams also worked with local social care organisations and care providers in 'knowledge exchange' groups which met throughout the project to share emergent themes from the research and create a deliberative space for discussing these from a range of perspectives.

Working in this way allows a different kind of understanding to emerge which encompasses the messy, complex realities of everyday life that cannot be captured within 'objective' measurement techniques. In doing this, it can show the specificities of (in this case) care needs in old age and how these may not have been considered in policy and practice and so can expose a gap in current understanding. The participants in our study revealed many aspects of their lives, such as loss and bereavement, identity, changing relationships as well as health that all form part of the background in which care is negotiated. In the next section we look at some of these experiences by focusing on two participants and themes that emerged in their accounts which illustrate how lived experience can problematise policy assumptions about care in old age.

\section{Two Examples of Lived Experiences of 'Choice'}

The promotion of 'choice' is the basis of current English social care policy, with the assumption that choice will empower people who need services:

people should have the power of choice about what services they receive.... Choice is about empowering people. ... incentivising providers to deliver the services that people want and choose for themselves and their families. (HM Government 2014, 1)

Whilst our participants may indeed have valued choice in principle, in line with Barnes (2012), their experiences told a rather different story about the extent and nature of consumer power in the context of needing care in later life. The constraints to exercising their 'choice', not articulated in the policy discourse, entail a combination of personal circumstances and market mechanisms coming into play with the nature of care 
needs in old age. Here we look in some detail at the accounts of two participants, Brenda and Iris, ${ }^{10}$ both of whom were trying to navigate the position of the 'consumer' as they attempted to get their needs for care met. Their stories are illustrative of themes that emerged in many of the experiences of the participants in the study and offer different perspectives on the notion of 'choice'.

Brenda, who was in her early eighties, had lived with physical disability affecting her mobility since her teenage years. As she got older her mobility had worsened and she had also developed a heart condition. She had been widowed for some time and lived on her own. During her working life Brenda had a successful career in financial services. She did not have children but had extended family (siblings, nieces and nephews) who lived close by. We first interviewed Brenda some eighteen months after a serious fall which had resulted in a hospital stay. Following her discharge from hospital, Brenda's care was organised, arranged and paid for by the NHS as part of a six-week rehabilitation process. Without prior warning, she was then left to sort out her ongoing care needs for herself. She described this as being "given a leaflet and expected to get on with it". She was immobile and needed assistance to go to the toilet, wash and dress, make meals and get into bed. She had some prior knowledge of care services, having lived with disability for a long time and had volunteered with a local care charity. She was also well organised and confident in using the Internet to find local care services and research their ratings from inspections carried out by the Care Quality Commission who regulate social care in the UK. In many respects she was comfortable with the process and had clear ideas about what she needed and what was important for her. In other words, she was trying to be an active responsible citizen and she spoke about the importance of remaining 'independent':

I try to be very independent and try and do things, well after my husband died. ... I was on my own ... and during that time I had one of my knee replacements and I was looking after my mother and working full time and, you know, you learn to be independent as much as possible because you have to be.

${ }^{10}$ These are not real names as we use pseudonyms to protect the anonymity of research participants. This forms part of the ethical approval from the National Social Care Research Ethics Committee which governs the research. 
The care package that Brenda had negotiated with a private care company involved a daily care visit of thirty minutes in the morning. The carers set Brenda up for the day ensuring that she had flasks of coffee and food as by this point Brenda was generally able to manage her personal care, although she had bad days where she struggled with dressing. Overall, Brenda was happy with her carers, but she had an ongoing issue over the timing of the care visits. This was the one area in which Brenda indicated strongly that she wanted to feel a sense of control and she had chosen an agency based on this 'choice'. But despite their original assurance that they could provide a call between 7.45 and 8 in the morning in practice this was unreliable and inconsistent, as Brenda explained:

[the care package] ... was ideal for a while but now it's gone completely down the pan ... you know, it goes on, you get a few weeks when it's alright and then all of a sudden it's not.

Brenda had voiced her dissatisfaction about this and had tried to negotiate the times she wanted with the agency that provided the care. However, she expressed feeling at a disadvantage in her dealings with the agency:

she (agency manager) knows that I've got no choice. ... Doesn't matter what I've asked for or that I've been having them for 18 months, you know, they just do what they like, so what do you do?

Brenda had explored the care options available to her and having had care for over eighteen months she had developed relationships with some of her carers. She also had a good understanding of the local care sector. She was very aware that the carers worked for low pay and that the agency that she used was not what she described as a good employer. For example, she knew that the carers were paid only half the amount that she was charged:

At the moment I'm paying $£ 8.57$ for half an hour and the carer gets $£ 4.50$.

Which is just under half and that's really not very fair is it?

This impacted Brenda in two ways. Firstly, she was reluctant to complain about the carers themselves, even if they were not doing exactly what she required of them. She felt a genuine sympathy and concern for them knowing that as workers they were not treated well. And secondly, she was aware of the issues in relation to recruiting care workers and that the 
systemic problems in the care sector meant that the unreliable, inconsistent service that she received and lack of choice over the timing of care visits would be a feature in all local care agencies. She was somewhat resigned to paying for a care service that did not meet her needs:

So I don't know quite honestly. ... of course you do realise that if you try somebody else, everybody's got the same problem. There's not enough carers so, so trying somebody else ... it's probably the devil you know is better than the devil you don't.

As the interview progressed it became clear that Brenda was somehow managing or even tolerating the situation and was quite fearful that her needs would increase. She worried that another fall may mean further hospitalisation, and this impacted on how she was living. She slept in a chair in her living room to avoid going upstairs and getting in and out of her bed. She depended on the sandwiches and flasks of coffee that the morning carers left to avoid standing on her feet and walking to the kitchen. She explained that she needed two lots of surgery on her heart and knee and that she had delayed this as it would most likely mean needing assistance with washing and going to the toilet. In part she was worried about the increased costs of the care she would need but also she had little confidence in the reliability of the agency and feared being left powerless in these circumstances.

Like Brenda, Iris was widowed and lived on her own. She was ninetytwo and had severe osteoporosis. She was at risk of breaking bones if she fell and had decreased mobility due to previous fractures. Iris had started having carers three years previously following a heart attack and a series of falls. The carers helped her with daily living tasks and took her out for shopping and social trips as she was unable to go out on her own. She managed her own personal care and bathing with the carers present in case she fell. She had ongoing heart problems for which she needed to take regular medication and the carers helped her with this.

Iris described how she was trying to manage and meet her care needs as something she felt she should do without depending on her family. She spoke about the sense of ongoing responsibility she felt for her family and this revealed the complex family dynamics which shaped her decisions. There had been a significant bereavement in the family five years earlier when Iris's daughter died. Her sons and grandchildren lived locally and although she saw them quite often, she did not rely on them to provide care. 
I have never asked for anything and there are not a lot of offers from the family. But it suits me.... we have never really switched from she is looking after us, now we look after her. We haven't ever got there. It's, I don't want to make my two sons sort of feel that they're responsible for my problems and they've got to solve them all, you know.

Iris knew she was struggling to cope with her current situation and following another fall she had begun to worry about being able to remain in her apartment. Like Brenda, she had been researching the options to meet her increasing needs for care. She described herself as 'a planner' always wanting to be prepared and know what was happening next. She had many leaflets and brochures about residential care and care services and had been looking for sources of financial advice. Much of this suggested that she was someone who was organised and who liked to be independent and in control. Yet she also spoke about feeling lonely for the first time in her life, and despite her insistence of not wanting her family to take care of her, there was ambivalence about this. She described how devastated she felt when one of her sons had recently taken up a job offer abroad and moved his family:

It's all been fairly drastic and dramatic and I'm not quite sure how to deal with it. It was a sort of indirect support, but for me, individually, it was an absolute shock, you know. ... But I have to get used to that.

She spoke about how she would love one of her granddaughters to move in with her but did not want her granddaughter to have the responsibility of looking after her. And whilst she was struggling to remain living in her apartment, she was clearly very reluctant to give it up as she regarded it as still the family home and somewhere for the family to gather and a place to stay if they needed to:

Yes, you see, because they always, always came together here, first in their old home, of course, and then always here, without question, I mean, that was understood that this is where they would be for Christmas ... made a big difference to us, when my daughter died.

The themes that emerge in Brenda and Iris's interviews are echoed in many of the accounts of older people who took part in the research who, although living in different individual contexts, were facing similar issues. Their stories illustrate kinds of journeys that we negotiate as we age, 
involving not only changes in our own capacities but also in our sense of self, of who we are and how we have perceived ourselves during our adult lives. Our feelings about declining independence and needing care from others have to be encountered, and for the people in our study, whilst also trying to work out how to resolve care needs via a market-based system of care. We can see that what apparently guides human behaviour according to neoliberal economic doctrine-maximising self-interest and making 'choices'-bears little relevance in this context. Iris and Brenda, and the other participants in our study, were dealing with far greater complexity. Not only was their capacity to choose bounded by a local social care market but also by the physical and emotional changes that can accompany ageing and by the relational nature of care itself. The enormous emotional, psychological and practical dimensions of these suggest that the economistic logic completely misses so much of what happens in reality. Decisions about care are not rational information-driven ones in the context of old age and ill health where uncertainty about the future and a sense of vulnerability may heavily feature. The assumption that the market provides the mechanism for fair exchange between equal players does not hold true in this context.

For the people in our study, having enough money to pay for care did not in itself guarantee any kind of consumer power. Moreover, their experiences show that their choices were not only, or exclusively, related to the amount and costs of care as they were dealing with difficult personal and interpersonal challenges which had also to be negotiated. They have experienced first-hand what happens when care is commodified, and how this is different from other purchasing decisions. Social care users in England are now expected to adopt the role of 'care consumer' and for self-funders this generally means that the transactions will happen between just them and the care provider with no neutral intermediary who might independently assess their needs. And these decisions are likely to be made at times when the person is already experiencing challenging issues, such as ill health, hospital discharge or other very stressful circumstances, so far from an ideal context in which to be making what are very impactful and possibly far-reaching decisions. Austerity has intensified this situation as local authority cuts mean not just that more people are directly paying for care but that there is less support from reduced community services and diminished oversight from statutory sources, leaving people to negotiate the vagaries of the social care market at a time of potentially substantial and increasing vulnerability. 


\section{Towards Caring Democracy: The Epistemological Dimension}

The themes that emerged in the experiences of our participants help to expose the fault lines of the current social care system in England. This not only illustrates the flaws in the underlying current assumptions of individual autonomy informing social care policy but also demonstrates how the same assumptions totally fail to understand the nature of care in old age as it is experienced. The key questions are what and how can these experiences contribute to thinking about caring democracy? Tronto's call to shift the focus from economic production to one that is concerned with care will necessarily require challenging the 'knowledge' that is produced by neoliberal systems of audit and measurement as the only legitimate form of knowledge about care. This is crucial as the wider political debate about care has been defined by this same neoliberal economic discourse limiting the boundaries to concerns about growing numbers of older people creating a 'burden' on resources that 'we' cannot afford.

In the current climate it would be easy to construct the welfare state as the golden age of welfare services. The post-war settlement saw the foundation of the NHS and a tax and welfare system based on redistribution. The provision of public services was based on ideals of universal coverage, a commitment to equality and social rights and addressing the inequalities produced by economic growth and market capitalism. But it is crucial to remember that it was always, despite the aspirations of universal coverage, an exclusive system, full of provisos and exceptions, and it was a gendered settlement that promoted traditional gendered norms. From the 1970s, feminist and disability activist movements have exposed and campaigned against these failings and exclusions. Moreover, what became so unavoidably obvious in the 'Windrush scandal' of $2018^{11}$ was the extent to which it was a colonial project (see Gentleman 2019). It was built, and indeed depended on, the labour of migrants from colonised countries who were themselves never truly included in its ideals and entitlements as full citizens. But what appears to have been lost in the UK is a 'public'

\footnotetext{
${ }^{11}$ As part of the UK immigration policy to create a 'hostile environment', thousands of people who had migrated from the Caribbean in the post-war period (known as the Windrush generation after one of the original ships that brought them to the UK) were wrongly classified as 'illegal immigrants'. Many were illegally deported, imprisoned, denied healthcare and lost their jobs and homes. The UK government finally admitted the mistake after many months of media reports by the Guardian in 2018.
} 
understanding of collective responsibility for care, although for many of the older generation, like the people who took part in our research, this has been an integral part of their understanding of citizenship. The wider cultural politics of individualism that has taken hold over time, the long game played by neoliberals, has happened insidiously without a full public debate on the democratic implications of these changes. So, the potential of the welfare state to be moving towards 'caring with' (Tronto 2013) is lost along with recognition of the value of 'the public' and collective responsibilities at a societal level.

On the ground the upheavals created by these transformations are evident in a system characterised by volatility and fragmentation, with complex and differing funding arrangements for health and social care. The result is a constantly 'shifting sands' system which is challenging for all who need to navigate it: those who work in it as well those who depend on it for care (National Audit Office 2018). The complexities of these changes have become obfuscated by the dominant neoliberal mantra of 'choice' and the common-sense logic of austerity ideology. This has done little to promote understanding or informed debate amongst a wider public about care, and questions about the division of responsibilities for care that we might aspire to in a democratic society. Indeed, such is the lack of public understanding about the current funding and organisation of social care that a widely held (mistaken) belief persists that the welfare state still provides 'cradle to grave' coverage, collectively funded through social insurance and tax contributions (National Audit Office 2018). ${ }^{12}$

Some have argued that it was the success of the social democratic welfare state that led to its downfall (Hall et al. 2015). Massey (2015) argues that even the limited redistribution and gains in social rights proved intolerable to capitalist interests and the result was the emergence of neoliberalism as a backlash against those gains. To succeed, the neoliberal backlash had to displace the shared 'public' understanding underpinning the welfare state- the commitment to social equality and the role of the state in guaranteeing it - and replace it with a new 'common sense' based on competitive individualism and market relations. Recognising the role that the terminology of neoliberalism plays in shaping our understanding is crucial,

${ }^{12}$ Ipsos MORI poll conducted in March 2018 found that large sections of the population wrongly think that social care services are free and provided by the NHS - $63 \%$ of population thought that NHS provided social care for older people and $49 \%$ thought that social care is free at the point of need (NAO 2018). 
as Massey argues the "whole vocabulary we use to talk about the economy, while presented as a description of the natural and the eternal, is in fact a political construction that needs contesting" (Massey 2015, 6-7).

A similar point is made by Metcalf (2017) who argues that we need to return to the origins of neoliberalism, to the actual group of men who called themselves 'neoliberals', whose aim and purpose was a 'revolution in economic thought' and trace the intellectual journey of their ideas. We need to be reminded that the 'free market' is a human invention and to see:

the extent to which a language formerly confined to chalkboard simplifications describing commodity markets (competition, perfect information, rational behaviour) has been applied to all of society, until it has invaded the grit of our personal lives, and how the attitude of the salesman has become enmeshed in all modes of self-expression. (Metcalf 2017 online)

To break through this and 'think differently', what Tronto (2017) has referred to as the need to replace homo economicus with homo politicus, what counts as relevant knowledge under neoliberalism needs critical examination. If 'caring democracy' requires the dismantling of the neoliberal hold, then a paradigm shift in what constitutes knowledge about care will be needed. An essential part of this is the epistemological dimension of care. Looking at lived experiences of those engaged in the daily giving and receiving of care is to engage with the evidence of what neoliberalism produces on the ground.

Neoliberal logic works through systems and services, including public services of health, education and care services, by audit and measurement of performance indicators. Only things that can be easily counted, (e.g. number of minutes per care visit or number of students registered on a course) are recognised as 'objective facts'. Metcalf (2017) has argued that the founding principles of neoliberalism in Hayek's ideas, that objective truth could only be discovered through the market, have been elevated to a kind of 'social omniscience'. This has penetrated not only the management of the commercial world but public health and care sectors where an audit culture prevails, and measurement based on statistics and performance indicators are the only tools used to produce 'intelligence' about the system. The potential understanding that could be drawn from (in the case of our study) the experience of people with care needs, who are on the receiving end of those systems, is outside of the neoliberal frame. Moreover, efforts to include service user knowledge in policy research and 
practice tend to be done through a consumerist model which limits this potential.

By contextualising the experiences of our participants as they negotiate the social care market the parameters of the 'crisis' become clear. It is not purely an economic crisis of excessive public expenditure and debt, as the government claims in order to manage the fiscal crisis in the banking sector. Nor is it not just a crisis in care for the lives of the millions of ordinary people who have been impacted by the austerity policies. It is a crisis of care and a crisis of democracy in the lack of public debate, agreement and decision-making on major and far-reaching decisions about the basic infrastructure of society.

Neoliberalism, as the doctrine that dominates all spheres of daily life today, impoverishes our capacity to think deeply about the meaning of our actions and experiences. By offering neat and tidy 'answers' (measurable, quantifiable, objective) it makes the complexity of human existence less visible. If we are to really think about care and in the case of our study, what care means as in old age and as we approach the end of our life, we must engage with this complexity and lived experience. The kinds of answers that neoliberalism provides are simply not fit for purpose as they are empty and meaningless in this context. To shift public understanding beyond the economic, to enable the political mobilisation of solidarity required for 'caring with' will indeed need breaking the stranglehold on our imagination of what is possible. Listening to the lived experiences of those engaged in the daily struggles of giving and receiving care in a whole range of contexts has the potential power to challenge the neoliberal narrative and how we think about care.

Acknowledgements We thank Beatrice Gahagan and Petr Urban for their detailed feedback on this chapter. We would also like to acknowledge the contribution of all the co-researchers and research teams in the Ethical Issues in Self-funded Social Care: Co-producing Knowledge with Older people project that this chapter draws on. This work was supported by the Wellcome Trust $[203363 / \mathrm{Z} / 16 / \mathrm{Z}]$.

\section{REFERENCES}

Association of Directors of Adult Social Services (ADASS). 2017. ADASS Budget Survey 2017. Leeds: Association of Directors of Adult Social Services.

Barnes, Marian. 2012. Care in Everyday Life: An Ethic of Care in Practice. Bristol: Policy Press.

Cameron, David. 2009. Hugo Young Lecture 10th November 2009. https://conservative-speeches.sayit.mysociety.org/speech/601246. Accessed November 2018. 
Care Quality Commission (CQC). 2018. State of Health and Adult Social Care in England 2017-18. Newcastle: Care Quality Commission.

Clarke, John, and Janet Newman. 2012. The Alchemy of Austerity. Critical Social Policy 32 (3): 299-319.

Clarke, John, Janet Newman, and Louise Westmarland. 2007. The Antagonisms of Choice: New Labour and the Reform of Public Services. Social Policy of Society 7 (2): 245-253.

Davies, William. 2012. The Emerging Neocommunitarianism. The Political Quarterly 83 (4): 767-776.

Department of Health (DH). 2010. Practical Approaches to Improving the Lives of Disabled and Older People through Building Stronger Communities. London: Department of Health.

Fotaki, Marianna. 2009. Are All Consumers the Same? Choice in Health, Social Care and Education in England and Elsewhere. Public Money \& Management 29 (2): 87-94.

Gentleman, Amelia. 2019. UK to Pay up to $£ 200 \mathrm{~m}$ in Compensation to Windrush Victims. Guardian, April 3. https://www.theguardian.com/uk-news/2019/ apr/03/uk-pay-windrush-victims-200m-compensation-lives-damaged-hostileenvironment-policy. Accessed 31 May 2019.

Glendinning, Caroline. 2017. Long-Term Care and Austerity in the UK - A Growing Crisis. In Long-Term Care for the Elderly in Europe: Developments and Prospects, ed. Bent Greve, 107-125. Oxford and New York: Routledge.

Hall, Stuart, Doreen Massey, and Michael Rustin, eds. 2015. After Neoliberalism? The Kilburn Manifesto. London: Lawrence and Wishart.

HM Government. 2014. Open Public Services Progress Report. London: Cabinet Office. https://www.gov.uk/government/publications/open-public-services2014-progress-report. Accessed 24 March 2019.

Humphries, Richard, Ruth Thorlby, Holly Holder, Patrick Hall, and Anna Charles. 2016. Social Care for Older People: Home Truths. London: The King's Fund.

Ismail, Mohamed, Shereen Hussein, Martin Stevens, John Woolham, Jill Manthorpe, Fiona Aspinal, Kate Baxter and Kritika Samsi. 2017. Do Personal Budgets Increase the Risk of Abuse? Evidence from English National Data. Journal of Social Policy 46 (2): 291-311.

Massey, Doreen. 2015. Vocabularies of the Economy. In After Neoliberalism? The Kilburn Manifesto, ed. Stuart Hall, Doreen Massey, and Michael Rustin, 3-16. London: Lawrence and Wishart.

Metcalf, Stephen. 2017. Neoliberalism: The Idea that Swallowed the World. Guardian, August 18. https://www.theguardian.com/news/2017/aug/18/ neoliberalism-the-idea-that-changed-the-world. Accessed 21 November 2018.

Mol, Annemarie. 2008. The Logic of Care: Health and the Problem of Patient Choice. London: Routledge.

National Audit Office (NAO). 2014. Adult Social Care in England: On Overview. London: National Audit Office. 
2018. The Health and Social Care Interface. Report of the Comptroller and Auditor General, National Audit Office, Ministry of Housing, Communities and Local Government, Department of Health and Social Care.

Stewart, Zoe. 2017. Passport checks for patients is an abandonment of NHS principles. Guardian April 7. https://www.theguardian.com/commentisfree /2017/apr/07/passport-checks-patients-nhs-principles-health-tourists. Accessed 14 August 2019.

Tanner, Denise, Lizzie Ward, and Mo Ray. 2018. 'Paying Our Own Way': Application of the Capability Approach to Explore Older People's Experiences of Self-Funding Social Care. Critical Social Policy 38 (2): 262-282.

Tronto, Joan C. 2013. Caring Democracy: Markets, Equity and Justice. New York: New York University Press.

- 2017. There Is an Alternative: Homines Curans and the Limits of Neoliberalism. International Journal of Care and Caring 1 (1): 27-43.

United Nations. 2019. Human Rights Council Visit to the United Kingdom of Great Britain and Northern Ireland: Report of the Special Rapporteur on Extreme Poverty and Human Rights. A/HRC/41/39/Add.l. United Nations General Assembly. https://documents-dds-ny.un.org/doc/UNDOC/GEN/ G19/112/13/PDF/G1911213.pdf?OpenElement. Accessed 14 August 2019. Ward, Lizzie, and Beatrice Gahagan. 2010. Crossing the Divide Between Theory and Practice: Research and an Ethic of Care. Ethics and Social Welfare 4 (2): 210-216.

Williams, Fiona, and Deborah Brennan. 2012. Care, Markets and Migration in a Globalising World: Introduction to the Special Issue. Journal of European Social Policy 22 (4): 355-362.

Open Access This chapter is licensed under the terms of the Creative Commons Attribution 4.0 International License (http://creativecommons.org/licenses/ by $/ 4.0 /)$, which permits use, sharing, adaptation, distribution and reproduction in any medium or format, as long as you give appropriate credit to the original author(s) and the source, provide a link to the Creative Commons licence and indicate if changes were made.

The images or other third party material in this chapter are included in the chapter's Creative Commons licence, unless indicated otherwise in a credit line to the material. If material is not included in the chapter's Creative Commons licence and your intended use is not permitted by statutory regulation or exceeds the permitted use, you will need to obtain permission directly from the copyright holder.

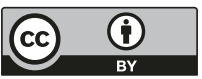

